\title{
Variation in the Prevalence of Antibiotic Resistance of Staphylococcus aureus from Human Skin and Nares
}

\author{
By W. C. NOBLE \\ Department of Bacteriology, Institute of Dermatology, \\ St John's Hospital for Diseases of the Skin, London E9 6BX
}

(Received I 2 May 1976)

\begin{abstract}
SUMMARY
Patients whose skins are colonized with Staphylococcus aureus resistant to penicillin and/or tetracycline may carry variants that are sensitive to these antibiotics. The skin of most individuals yields the fully resistant type as the predominant flora and the nose harbours the sensitive version. This probably represents plasmid loss in vivo. The plasmid-positive cells were not more resistant to desiccation or more deeply pigmented than plasmid-negative cells. The explanation for such distributions is unknown.
\end{abstract}

\section{INTRODUCTION}

Few of the factors which affect growth of micro-organisms on the skin are well understood, although increased relative humidity and temperature cause an increase in the total flora and the application of antibiotics causes changes in the flora. The factors which permit colonization by Staphylococcus aureus of the skin of patients with eczema and psoriasis or prevent colonization in a normal host are not known, though these might include requirement for specific nutrients or the presence of antibiotic-producing strains amongst the normal flora.

Microbial variants which differ in some easily measured property have been studied extensively in vitro, but have been examined less often in their natural habitat. Two resistance markers are well characterized in $S$. aureus; these are penicillinase production and tetracycline resistance. The genes controlling these resistances are located on separate plasmids (Lacey, I975). The penicillinase plasmid carries information for heavy metal ion resistance and some other properties; the other plasmid governs only tetracycline resistance in the strains so far examined. The genes for pigment production are not carried by the above plasmids but are linked to resistance to desiccation and to linoleic acid, a component of human sebum (Grinsted \& Lacey, 1973).

In 1972, Noble reported strains of $S$. aureus obtained from patients with skin disease in which antibiotic resistance appeared to be lost in vivo. This paper reports further studies on unstable antibiotic resistance in staphylococci in their natural habitat.

\section{METHODS}

Patients were swabbed in the nose, on the chest, perineum, right and left forearms, and right and left thighs using cotton-tipped swabs moistened in nutrient broth. The swabs were inoculated on to blood agar (Oxoid blood agar base containing $7 \%$ lysed horse blood) and incubated for $24 \mathrm{~h}$ at $37^{\circ} \mathrm{C}$; five plates were used for each swab.

All single colonies of $S$. aureus on selected plates were subcultured and tested for resis- 
tance to penicillin and tetracycline on a blood agar medium. The criterion for resistance to an antibiotic was an inhibition zone less than $2 \mathrm{I} \mathrm{mm}$ diameter surrounding a disc containing Io units of penicillin, or $18 \mathrm{~mm}$ surrounding a disc containing $30 \mu \mathrm{g}$ tetracycline on Difco Mueller-Hinton medium containing lysed horse blood.

Attempts to induce variants that were antibiotic sensitive or had altered pigmentation were made using Oxoid nutrient broth containing ethidium bromide ( $\mathrm{I} \mathrm{mg} \mathrm{l}^{-1}$ ) or dithranol (saturated) incubated at 37 or $43{ }^{\circ} \mathrm{C}$. Dithranol (I,8,9-trihydroxyanthracene) is used extensively in the treatment of psoriasis and has been shown to induce mutants in yeasts (Gillberg, Zetterberg \& Swanbeck, 1967). Serial Io-fold dilutions were made and all single colonies from suitable plates were tested as above.

Staphylococci were inoculated on to porcine skin used in burns treatment (Lyoderm Armour Pharmaceutical Co., Phoenix, Arizona, U.S.A.) to study their survival on drying. The skin was divided into I cm squares and saturated with Murphy's synthetic sweat solution (Murphy, 1975). Some squares were also treated with the ether-soluble fraction of human sebum, approximately $0.4 \mathrm{mg}$ sebum being added to each square. Washed staphylococci suspended in Murphy's synthetic sweat solution were inoculated on to the squares which were allowed to dry at room temperature with uncontrolled relative humidity. Survival curves were obtained by vigorously shaking squares of skin bearing staphylococci in buffer $\mathrm{pH} 8.0$ containing $0.5 \%(\mathrm{v} / \mathrm{v})$ Tween 80 on a mechanical shaker for I min; dilutions were then inoculated on to blood agar and the colonies were counted after $24 \mathrm{~h}$ incubation at $37^{\circ} \mathrm{C}$. Duplicate samples were used in each instance.

Representative samples were phage-typed using the internationally agreed set of phages. Isolates were assumed to be of the same origin if the phage lysis pattern was the same.

Pigment production was stúdied on Oxoid blood agar base medium alone or with the addition of Tween $80(0 . \mathrm{I} \%, \mathrm{v} / \mathrm{v})$, squalene $(0 . \mathrm{I} \% \mathrm{v} / \mathrm{v})$, or glycerol monoacetate $(0 . \mathrm{I} \%$, $\mathrm{v} / \mathrm{v}$ ) (Willis \& Turner, I962), or with both Tween 80 and squalene (each $0 . \mathrm{I} \%$, v/v). Bacteria were scraped off the plates in saline and washed by centrifuging. Pigment was extracted in methanol for $30 \mathrm{~min}$ at $90^{\circ} \mathrm{C}$ and its spectrum was examined. Pure $\beta$-carotene (Sigma) was used as a standard.

\section{RESULTS}

A systematic search for strains of staphylococci with variations in antibiotic resistance has not been carried out, but in 3 months Io patients were identified from routine clinical specimens as carrying $S$. aureus strains of more than one sensitivity pattern. These patients were amongst 152 with eczema or psoriasis, 106 of whom yielded $S$. aureus from skin swabs.

Thirty patients were examined at all carriage sites; 16 had staphylococci that were $95 \%$ or more consistent at all sites and are not included in further analyses, except to note that in only three instances were the sensitive varieties more numerous than resistant varieties. Ten patients carried strains varying in their resistance to tetracycline and four to penicillin. The strains and their characteristics are shown in Table $I$ in the order of detection. No particular phage type was encountered, though two pairs of patients may have carried the identical strain (7 and 8, 9 and II).

Table 2 shows the distribution of the resistant and sensitive variants on the body surface. In general, with both penicillin and tetracycline, the skin carried the largest proportion of resistant isolates and the nose the sensitive ones. Isolates from the perineum followed the 'skin' pattern rather than the 'nose' pattern. On 12 occasions the skin flora possessed proportionately more than twice as many resistant cells as the nose; on no occasion did the 

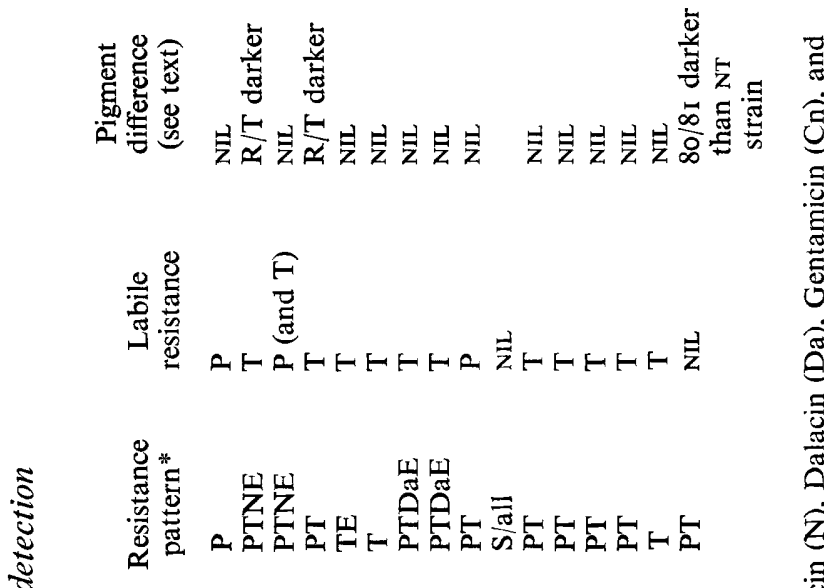
Table 2. Distribution of resistance variants and number of isolates tested

\begin{tabular}{|c|c|c|c|c|c|c|c|c|c|}
\hline \multirow[b]{2}{*}{ Patient } & \multirow[b]{2}{*}{ Date } & \multirow{2}{*}{$\begin{array}{l}\text { Labile } \\
\text { resis- } \\
\text { tance }\end{array}$} & \multicolumn{3}{|c|}{ No. of isolates tested } & \multicolumn{3}{|c|}{$\begin{array}{l}\text { Percentage with resistance } \\
\text { pattern }\end{array}$} & \multirow{2}{*}{$\frac{\% \text { R skin }}{\% \text { R nose }}$} \\
\hline & & & Nose & Skin* & Perineum & Nose & Skin* & Perineum & \\
\hline I & $27 / \mathrm{Jul} / 73$ & $\mathbf{P}$ & 40 & 268 & NSA & I0 & 95 & 一 & $9 \cdot 50$ \\
\hline 3 & 19/Apr/74 & $\mathbf{P}$ & 234 & 926 & 88 & 9 & 5 & 7 & 0.56 \\
\hline admit & 7/Nov/75 & $\mathbf{P}$ & 160 & 485 & NSA & 92 & 100 & - & $\mathrm{I} \cdot 08$ \\
\hline 8 & $8 / \mathrm{May} / 75$ & $\mathbf{P}$ & 298 & 625 & $20 I$ & 5 & 91 & 82 & $18 \cdot 20$ \\
\hline \multirow[t]{5}{*}{9} & II /Jun/75 & $\mathbf{P}$ & 165 & 660 & NSA & 98 & 68 & - & 0.69 \\
\hline & $18 / \mathrm{Jun} / 75$ & $\mathbf{P}$ & 200 & I04 & NSA & $98 \cdot 5$ & 97 & - & 0.98 \\
\hline & I9/Jun/75 & $\mathbf{P}$ & 632 & 397 & NSA & 97 & 97 & - & $1 \cdot 00$ \\
\hline & $\mathrm{II} / \mathrm{Jul} / 75$ & $\mathbf{P}$ & 84 & I 28 & NSA & 90 & 99 & 一 & $I \cdot 10$ \\
\hline & 5/Aug/75 & $\mathbf{P}$ & 224 & 152 & NSA & 99.5 & 100 & 一 & 1.00 \\
\hline \multirow[t]{2}{*}{2} & 2/Aug/73 & $T$ & 76 & 500 & NSA & $8 \mathrm{I}$ & 89 & - & $1 \cdot 10$ \\
\hline & $\mathrm{I} / \mathrm{May} / 74$ & $\mathrm{~T}$ & 377 & 245 & 161 & I4 & 89 & 97 & $6 \cdot 36$ \\
\hline 4 & $8 /$ Oct $/ 74$ & $\mathrm{~T}$ & 298 & 339 & NSA & IO & 84 & - & $8 \cdot 40$ \\
\hline 5 & $30 / \mathrm{Sep} / 74$ & $\mathrm{~T}$ & 295 & 743 & 66 & 42 & 87 & 97 & $2 \cdot 07$ \\
\hline admit & I9/Dec/74 & $\mathrm{T}$ & 331 & 392 & NSA & 82 & 96 & - & $1 \cdot 17$ \\
\hline 6 & $18 / \mathrm{Feb} / 75$ & $\mathbf{T}$ & 272 & 467 & NSA & 20 & $4 \mathrm{I}$ & 一 & 2.05 \\
\hline 7 & II $/ A p r / 75$ & $\mathrm{~T}$ & 296 & 160 & NSA & 97 & 86 & - & 0.89 \\
\hline \multirow[t]{2}{*}{ Io } & $23 /$ Jun $/ 75$ & $\mathrm{~T}$ & 128 & $23 \mathrm{I}$ & 160 & 3 & 13 & 100 & $4 \cdot 33$ \\
\hline & $25 /$ Jun/75 & $\mathrm{T}$ & II 2 & 144 & ND & I & 4 & 一 & 4.00 \\
\hline \multirow[t]{3}{*}{ II } & $4 / \mathrm{Jul} / 75$ & $\mathrm{~T}$ & 112 & 40 & NSA & 100 & 97 & 一 & 0.97 \\
\hline & $9 / \mathrm{Jul} / 75$ & $\mathrm{~T}$ & I 28 & 137 & NSA & 98 & 97 & - & 0.99 \\
\hline & $\mathrm{I} 6 / \mathrm{Jul} / 75$ & $\mathrm{~T}$ & 120 & 128 & 8 & 99 & 84 & 100 & 0.85 \\
\hline \multirow[t]{2}{*}{12} & 14/Aug/75 & $\mathrm{T}$ & 136 & 585 & NSA & I & 7 & - & 7.00 \\
\hline & $8 / \mathrm{Sep} / 75$ & $\mathrm{~T}$ & II 2 & 624 & 72 & 100 & 100 & 100 & $\mathrm{I} \cdot 00$ \\
\hline \multirow[t]{2}{*}{13} & $3 / \mathrm{Sep} / 75$ & $\mathbf{T}$ & 42 & 465 & ND & 84 & 56 & - & 0.67 \\
\hline & II $/ \mathrm{Sep} / 75$ & $\mathrm{~T}$ & I6 & 496 & NSA & 75 & 65 & - & 0.87 \\
\hline \multirow[t]{5}{*}{14} & $7 / \mathrm{Nov} / 75$ & $\mathbf{T}$ & 136 & 379 & 128 & 46 & 83 & 100 & $\mathrm{I} \cdot 80$ \\
\hline & $27 /$ Nov/75 & $\mathrm{T}$ & II9 & 212 & 204 & io & 87 & 88 & $8 \cdot 70$ \\
\hline & $30 / \mathrm{Jan} / 76$ & $\mathrm{~T}$ & 33 & $38 \mathrm{I}$ & ND & 42 & 53 & - & $I \cdot 26$ \\
\hline & $3 / \mathrm{Feb} / 76$ & $\mathrm{~T}$ & 69 & 267 & ND & 19 & 73 & 一 & $3 \cdot 84$ \\
\hline & $9 / \mathrm{Feb} / 76$ & $\mathrm{~T}$ & 117 & I44 & ND & 9 & 60 & - & $6 \cdot 67$ \\
\hline
\end{tabular}

ND, Not done; NSA, No $S$. aureus; P, Penicillin; T, Tetracycline.

* All skin sites other than the nose and perineum are combined in this group. There was no discernable difference in the various sites.

nose possess twice as many resistant variants as the skin. On the other 18 sampling days the ratio lay between these values. This suggests that the skin tends to select resistant variants (or that the nose tends to select sensitive variants).

Because the distribution of resistant and sensitive variants might result from differences in selection pressure at different sites, an attempt was made to investigate some of the factors which might be relevant.

\section{Plasmid loss in vitro}

Plasmid loss was examined after growth at $43{ }^{\circ} \mathrm{C}$ and by the use of ethidium bromide or dithranol. The results (Table 3 ) show that strains from five out of six patients had sensitive variants, usually in small numbers. However, when these strains were stored at room temperature for 3 to 4 months on blood agar base slopes, loss of resistance occurred at higher frequencies. Loss of resistance under these circumstances was noted originally by Barber (1949). Little loss was induced by dithranol, although ethidium bromide and growth at $43{ }^{\circ} \mathrm{C}$ were effective. The sensitive variants were always of the same phage type as that of the parent strain. 
Table 3. Plasmid loss in vitro

\begin{tabular}{|c|c|c|c|c|c|c|}
\hline Strain from patient 2 & Control & $\begin{array}{l}\text { Ethidium } \\
\text { bromide at } \\
37^{\circ} \mathrm{C}\end{array}$ & $\begin{array}{l}\text { Dithranol at } \\
\qquad 37^{\circ} \mathrm{C}\end{array}$ & $\begin{array}{l}\text { Growth at } \\
43^{\circ} \mathrm{C}\end{array}$ & $\begin{array}{c}\text { Ethidium } \\
\text { bromide at } \\
43^{\circ} \mathrm{C}\end{array}$ & $\begin{array}{l}\text { Storage } \\
\text { on Bijou } \\
\text { slope }\end{array}$ \\
\hline $\begin{array}{l}\text { No. tested for } \\
\text { altered pigment }\end{array}$ & 13400 & 3940 & 23980 & 13000 & ND & ND \\
\hline $\begin{array}{l}\text { No. of altered } \\
\text { pigmented variants }\end{array}$ & 0 & 0 & 0 & 0 & - & - \\
\hline No. tested for $\mathrm{R} / \mathrm{T}$ & ND & ND & ND & 296 & 360 & ND \\
\hline $\begin{array}{l}\text { No. of sensitive } \\
\text { variants }\end{array}$ & - & - & - & 0 & 0 & - \\
\hline \multicolumn{7}{|l|}{ Strain from patient 3} \\
\hline No. tested for $\mathrm{R} / \mathrm{PT}$ & 1746 & 2909 & ND & $87 \mathrm{I}$ & ND & 88 \\
\hline $\begin{array}{l}\text { No. of sensitive } \\
\text { variants* }\end{array}$ & 0 & $\begin{array}{r}60 \mathrm{~S} / \mathrm{P} \\
\text { I } \mathrm{S} / \mathrm{T}\end{array}$ & - & I $\mathrm{S} / \mathrm{T}$ & - & $\begin{array}{l}8 \mathrm{~S} / \mathrm{P} \\
4 \mathrm{~S} / \mathrm{T}\end{array}$ \\
\hline \multicolumn{7}{|l|}{ Strain from patient 5} \\
\hline $\begin{array}{l}\text { No. tested for } R / T \\
\text { No. of sensitive } \\
\text { variants }\end{array}$ & $\begin{array}{r}960 \\
0\end{array}$ & $\begin{array}{l}\mathrm{I046} \\
2 \mathrm{~S} / \mathrm{T}\end{array}$ & ${ }^{176} \mathrm{~S} / \mathrm{T}$ & $\begin{array}{r}568 \\
0\end{array}$ & $\stackrel{752}{7 \mathrm{~S} / \mathrm{T}}$ & $\begin{array}{l}224 \\
105 \mathrm{~S} / \mathrm{T}\end{array}$ \\
\hline \multicolumn{7}{|l|}{ Strain from patient 9} \\
\hline No. tested for $\mathrm{R} / \mathrm{PT}$ & 1160 & 1432 & 896 & 584 & ND & $21 \mathrm{I}$ \\
\hline $\begin{array}{l}\text { No. of sensitive } \\
\text { variants }\end{array}$ & $4 \mathrm{~S} / \mathrm{T}$ & $\begin{array}{r}32 \mathrm{~S} / \mathrm{P} \\
\mathrm{I} S / T\end{array}$ & 0 & $8 \mathrm{~S} / \mathrm{T}$ & - & $\begin{array}{l}15 \mathrm{~S} / \mathrm{T} \\
12 \mathrm{~S} / \mathrm{P}\end{array}$ \\
\hline \multicolumn{7}{|l|}{ Strain from patient $\mathrm{I}_{3}$} \\
\hline $\begin{array}{l}\text { No. tested for } \mathrm{R} / \mathrm{PT} \\
\text { No. of sensitive } \\
\text { variants }\end{array}$ & $\begin{array}{r}1304 \\
0\end{array}$ & $\begin{array}{l}1128 \\
\quad 12 S / P\end{array}$ & $\begin{array}{l}944 \\
\text { IS } / P\end{array}$ & ${ }_{\text {I S } / P}^{239}$ & ND & $\begin{array}{l}280 \\
22 \mathrm{~S} / \mathrm{P}\end{array}$ \\
\hline \multicolumn{7}{|l|}{ Strain from patient 14} \\
\hline $\begin{array}{l}\text { No. tested for R/PT } \\
\text { No. of sensitive } \\
\text { variants }\end{array}$ & $\begin{array}{r}884 \\
0\end{array}$ & ${ }_{\text {I } S / P}^{448}$ & $\begin{array}{r}2000 \\
0\end{array}$ & ${ }_{3}^{271} \mathrm{~S} / \mathrm{T}$ & ND & $\begin{array}{l}\text { II } 2 \\
4 S / P\end{array}$ \\
\hline
\end{tabular}

ND, Not done; R/PT, resistant to penicillin and tetracycline; R/P, S/P, resistant or sensitive to penicillin; $\mathrm{R} / \mathrm{T}, \mathrm{S} / \mathrm{T}$, resistant or sensitive to tetracycline.

* All variants had same phage type as parent strain.

Plasmid loss in vitro may not accurately represent events in vivo. Patient 14 carried two strains of $S$. aureus for most of her stay in hospital. One was a golden pigmented phage type 8o/8I strain resistant to penicillin and tetracycline (R/PT) and apparently acquired in hospital; it did not appear to produce variants in vivo (in 460 colonies tested, no variants were found). The other was a non-typable, pale-pigmented strain with variable resistance to tetracycline (all were penicillin sensitive). Antibiotic-sensitive variants obtained from the golden R/PT strain in vitro retained pigmentation and sensitivity to phages 80 and $8 \mathrm{I}$. This also suggests that the pale penicillin-sensitive strain was not derived from the pigmented resistant $80 / 8 \mathrm{I}$ strain.

\section{Pigmentation}

Pigmentation might be important in two ways. The major pigments in $S$. aureus are carotenoids which might protect the organism against sunlight. However, this seems unlikely to be significant here because the perineum is rarely exposed to direct sunlight. 
Table 4. Percentage survival of staphylococci on pig epithelium after 7 days at room temperature with uncontrolled humidity: the skin was saturated with synthetic sweat, or synthetic sweat and sebum

\begin{tabular}{|c|c|c|c|c|}
\hline \multirow{2}{*}{\multicolumn{2}{|c|}{$\begin{array}{l}\text { Strain from } \\
\text { patient no. }\end{array}$}} & \multicolumn{3}{|c|}{ Survivors $(\%)$} \\
\hline & & \multicolumn{2}{|c|}{ Skin plus sweat } & $\begin{array}{l}\text { Skin plus sweat } \\
\text { and sebum }\end{array}$ \\
\hline 2 & $\begin{array}{l}\text { R/T dark } \\
\text { S/T light }\end{array}$ & $\begin{array}{l}39^{a} \\
10^{a}\end{array}$ & $\begin{array}{l}8^{e} \\
4^{e}\end{array}$ & $\begin{array}{r}4 \mathrm{I}^{a} \\
7^{a}\end{array}$ \\
\hline 3 & $\begin{array}{l}\mathrm{R} / \mathrm{P} \\
\mathrm{S} / \mathrm{P}\end{array}$ & $\begin{array}{l}12^{b} \\
54^{b}\end{array}$ & - & - \\
\hline 5 & $\begin{array}{l}\mathrm{R} / \mathrm{T} \\
\mathrm{S} / \mathrm{T}\end{array}$ & $\begin{array}{l}49^{c} \\
62^{c}\end{array}$ & $\begin{array}{l}62^{e} \\
19^{e}\end{array}$ & $\begin{array}{l}37^{c} \\
34^{c}\end{array}$ \\
\hline 6 & $\begin{array}{l}R / T \\
S / T\end{array}$ & $\begin{array}{l}27^{d} \\
28^{d}\end{array}$ & - & $\begin{array}{l}20^{d} \\
35^{d}\end{array}$ \\
\hline 9 & $\begin{array}{l}\mathrm{R} / \mathrm{P} \\
\mathrm{S} / \mathbf{P}\end{array}$ & $\begin{array}{l}22^{b} \\
23^{b}\end{array}$ & - & - \\
\hline 12 & $\begin{array}{l}\mathbf{R} / \mathbf{P} \text { dark } \\
\mathbf{R} / \mathbf{P} \text { light }\end{array}$ & $\begin{array}{l}21^{b} \\
23^{b}\end{array}$ & - & 二 \\
\hline 14 & $\begin{array}{l}\mathrm{R} / \mathrm{P} \\
\mathrm{S} / \mathrm{P}^{*}\end{array}$ & $\begin{array}{l}59^{b} \\
45^{b}\end{array}$ & - & - \\
\hline
\end{tabular}

-, Test not done. $a, b, c, d, e$, represent separate experiments, thus conditions were identical for all figures marked $a$, etc. Other abbreviations as in Table 3.

* Obtained during experiments in vitro from 80/8I R/PT strain.

Squalene is a precursor of carotene and may form about $10 \%$ of human sebum; the ability of an organism to utilize squalene may be of benefit to it. However, difference in pigment production between the sensitive and resistant variants was only rarely detectable, either visually or spectrophotometrically, and culture in the presence of squalene depressed pigmentation in seven out of eight strains tested.

\section{Survival on desiccation}

The survival on drying, on pig skin saturated with synthetic sweat solution, may not closely represent survival on human skin under normal conditions. However, other experimental models are probably even further from reality. No consistent pattern emerged from these studies (Table 4), even sebum was not uniformly inimical to survival.

\section{DISCUSSION}

The nose and perineum are the usual sites of growth of $S$. aureus in persons without skin disease but in the patients described here, the number of organisms that were recovered and the frequency of recovery suggested that the organisms were resident and multiplying on several parts of the skin surface. Resistant variants were found more often on the skin surface (including the perineum) than in the nose.

This distribution could be the result either of selection for resistance on the skin or for sensitivity in the nose; the former seems more likely if it is assumed that carriage and replication of a plasmid imposes a 'load' on the organism in most environments; i.e. plasmids would be expected to be maintained only where they are 'necessary'. It is possible that the different growth rates in habitats might account for the differences in distribution (strains lacking plasmids growing faster in the nose). This would be difficult to test experi- 
mentally in vivo unless a labelled strain could be introduced; the difficulty of establishing $S$. aureus in carrier sites without the help of antibiotics or occlusion would militate against success. Acquisition of plasmids by staphylococci is a remote possibility here, though it can occur experimentally on the skin surface (Lacey, I975), and transfer of plasmids may also theoretically occur between coagulase-positive and coagulase-negative cocci ( $\mathrm{Yu} \&$ Baldwin, 197I).

Grinsted \& Lacey (1973) reported that deeply pigmented strains survived drying and exposure to linoleic acid better than non-pigmented variants. Lacey (1972) had previously reported that antibiotic-resistant variants showed no difference in survival on glass. In the present series, there were no striking differences in pigmentation, though two patients ( 2 and I2) had strains with slight differences; no consistent difference in survival could be related to pigmentation. This is perhaps not unexpected since only cells with no pigmentation at all were found to have reduced survival capacity by Grinsted \& Lacey(I973). In the present series, most variants had apparently identical pigmentation to the parent strain and no differences in survival on drying could be found. Squalene may constitute about $10 \%$ of human sebum (Noble \& Somerville, 1974) and dehydrosqualene can accumulate in $S$. aureus strains that have lost the ability to synthesize complete carotenoid pigments (Suzue, Tsukada \& Tanaka, 1968). Utilization of squalene may be expected to be associated with high pigmentation. However, squalene depressed pigmentation in most of the isolates tested. The incorporation of glycerol monoacetate into agar enhanced pigmentation equally in parent and variant isolates.

No attempt was made in these experiments to examine the remainder of the skin flora for antibiotic production (in most patients $S$. aureus was the predominant member of the flora). Amongst the resident skin flora, members of the Micrococcaceae produce antibiotics (Selwyn, 1975) as do dermatophyte fungi (Youssef et al., 1976). The contribution of these organisms to the ecology of $S$. aureus in vivo is unclear. The therapeutic antibiotic exposure of these patients seems unlikely to account for the distribution observed, as none had been treated with tetracycline or penicillinase-vulnerable penicillins.

Factor(s) that select or maintain the fully resistant parent organism on the skin are thus obscure. Antibiotic resistance, though easily measured, is unlikely to give the cell an advantage in vivo here. However, the penicillinase plasmid may carry other information. For example, in Staphylococcus epidermidis the penicillinase plasmid may also control the uptake of mannitol and $\beta$-glucosides, ribose fermentation and phospho- $\beta$-glucosidase activity; phage absorption, restriction and modification and growth factor requirements are also associated with penicillinase production (Schaefler, 1972). In S. aureus, resistance to cadmium and mercury may be closely associated with penicillinase production but even exposure of people to mercury may not result in the selection of resistant strains of staphylococci (Groves et al., 1975).

Further examination of the ecological pressures that result in the selection or maintenance of resistant or sensitive variants on the skin and nose are required.

I am grateful to Dr K. G. H. Dyke for a gift of ethidium bromide and to the consultant staff of St John's Hospital for access to patients in their care. 


\section{REFERENCES}

BARBER, M. (1949). The incidence of penicillin-sensitive variant colonies in penicillinase-producing strains of Staphylococcus pyogenes. Journal of General Microbiology 3, 274-281.

Gillberg, B. O., ZetTerberg, G. \& Swankeck, G. (1967). Petite mutants induced in yeast by dithranol (1,8,9-trihydroxyanthracene), an important therapeutic agent in psoriasis. Nature, London 214, 415.

GrINSTED, J. \& LACEY, R. W. (1973). Ecological and genetic implications of pigmentation in Staphylococcus aureus. Journal of General Microbiology 75, 259-267.

Groves, D. J., Short, H., Thewaini, A. J. \& Young, F. E. (1975). Epidemiology of antibiotic and heavy metal resistance in bacteria : resistance patterns in staphylococci isolated from populations in Iraq exposed and not exposed to heavy metals or antibiotics. Antimicrobial Agents and Chemotherapy 7, 622-628.

LACEY, R. W. (1972). Effect of antibiotic resistance on the survival of Staphylococcus aureus. Journal of Clinical Pathology 25, 713-715.

LACEY, R. W. (I975). Antibiotic resistance plasmids of Staphylococcus auretis and their clinical importance. Bacteriological Reviews 39, I-32.

MURPHY, C. T. (1975). Nutrient materials and the growth of bacteria on human skin. Transactions of St John's Hospital Dermatological Society 6r, 5I-57.

NoBLE, W. C. (1972). Loss of antibiotic resistance in staphylococci from a skin hospital. Lancet $i$, 929-93I.

Noble, W. C. \& Somerville, D. A. (1974). Microbiology of Human Skin. London: W. B. Saunders.

SCHAFFLER, S. (1972). Polyfunctional penicillinase plasmid in Staphylococcus epidermidis: Bacteriophage restriction and modification mutants. Journal of Bacteriology 112, 697-706.

SelwyN, S. (1975). Natural antibiosis among skin bacteria as a primary defence against infection. British Journal of Dermatology 93, 487-493.

Suzue G., TsuKada, K. \& TANaka, S. (1968). Occurrence of dehydro-squalene $\left(C_{30}\right.$ Phytoene) in Staphylococcus aureus. Biochimica et biophysica acta $\mathbf{1 6 4}, 88-93$.

Willis, A. T. \& TURNER, G. C. (1962). Staphylococcal lipolysis and pigmentation. Journal of Pathology and Bacteriology 84, 337-347.

Youssef, N., Wyborn, C., Holt, G., Noble, W. C. \& Clayton, Y. M. (I976). Production of antibiotics by dermatophyte fungi. Journal of Medical Microbiology 9 , P viii-ix.

YU, L. \& BALDWIN, J. N. (I97I). Intraspecific transduction in Staphylococcus epidermis and interspecific transduction between Staphylococcus aureus and Staphylococcus epidermidis. Canadian Journal of Microbiology 17, 767-773. 